This item was submitted to Loughborough's Research Repository by the author.

Items in Figshare are protected by copyright, with all rights reserved, unless otherwise indicated.

\title{
Perceived parental behaviors and next generation engagement in family firms: a social cognitive perspective
}

PLEASE CITE THE PUBLISHED VERSION

https://doi.org/10.1177/1042258718796087

PUBLISHER

SAGE Publications

VERSION

AM (Accepted Manuscript)

\section{PUBLISHER STATEMENT}

This work is made available according to the conditions of the Creative Commons Attribution-NonCommercialNoDerivatives 4.0 International (CC BY-NC-ND 4.0) licence. Full details of this licence are available at: https://creativecommons.org/licenses/by-nc-nd/4.0/

\section{LICENCE}

CC BY-NC-ND 4.0

\section{REPOSITORY RECORD}

Garcia, Patrick Raymund James M., Pramodita Sharma, Alfredo De Massis, Mike Wright, and Louise Scholes. 2018. "Perceived Parental Behaviors and Next Generation Engagement in Family Firms: A Social Cognitive Perspective". figshare. https://hdl.handle.net/2134/32188. 


\title{
PERCEIVED PARENTAL BEHAVIORS AND NEXT-GENERATION ENGAGEMENT IN FAMILY FIRMS: A SOCIAL COGNITIVE PERSPECTIVE
}

\author{
Patrick Raymund James M. Garcia \\ Department of Management \\ Macquarie University \\ (corresponding author) \\ Pramodita Sharma \\ Grossman School of Business \\ University of Vermont \\ and \\ Kellogg School of Management, Northwestern University, USA
}

\author{
Alfredo De Massis \\ Faculty of Economics and Management \\ Free University of Bolzano \\ and \\ Lancaster University Management School, UK
}

Mike Wright

The Centre for Management Buy-out Research

Imperial College

and

ETH, Zurich

Louise Scholes

Institute for Innovation and Entrepreneurship

Loughborough University London

\section{Accepted for publication in Entrepreneurship Theory and Practice.}

If you need to cite, please cite as:

Garcia, P.R.J., Sharma, P., De Massis, A., Wright, M., Scholes, L. (2018). Perceived parental behaviors and next generation engagement in family firms: A social cognitive perspective. Entrepreneurship Theory \& Practice, Forthcoming. 


\section{PERCEIVED PARENTAL BEHAVIORS AND NEXT-GENERATION ENGAGEMENT IN FAMILY FIRMS: A SOCIAL COGNITIVE PERSPECTIVE}

Next-generation engagement is a key contributor to the success and continuity of family firms. Family relationships are an important factor in shaping such engagement. However, we know little as to how this engagement process unfolds, especially during the formative years of nextgeneration members. Using the principles of social cognitive theory and drawing on the career development, organizational behavior, and family business literature, we theorize the indirect influence of perceived parental support and psychological control on next-generation engagement in family firms through the mediating variables of self-efficacy and commitment to the family business. We discuss several possible avenues to test and extend this model in future research.

\section{INTRODUCTION}

The intention to pass on control of the business to the next generation is an important distinguishing factor between family and non-family firms (Chua, Chrisman, \& Sharma, 1999). However, such intention can only become a reality when next-generation family members are willing and able to contribute to the success and continuity of their family firm (De Massis,

Kotlar, Chua, \& Chrisman, 2014). Despite the inherent importance of intrafamily succession to many incumbent family firm leaders, global studies reveal that next-generation family members have low levels of interest and intention to work in their parents' business (Zellweger, 2017). For instance, $80.3 \%$ of the 122,000 students surveyed in 1,000 universities across 50 countries intend to become employees upon graduation, $8.8 \%$ want to start their own business but only $2.7 \%$ expect to join their family business. Five years after graduation, a pattern of 'employee first, then founder' emerges, whereby $38.2 \%$ expect to own a business, but only $4.8 \%$ see themselves as working in their family business (Sieger, Fueglistaller, \& Zellweger, 2016). In the context of an aging population and many family business leaders' desire to transfer their business to nextgeneration family members, these numbers are alarming. 
Despite the global succession crisis, understanding the factors influencing next-generation engagement is limited. This gap reflects the skew of family business literature toward incumbents rather than next-generation members (De Massis, Sieger, Chua, \& Vismara, 2016), and the emphasis of succession literature on firm level processes and outcomes rather than on individual or family level predictors (Daspit, Holt, Chrisman, \& Long, 2016; Jaskiewicz \& Dyer, 2017). Efforts are underway to integrate insights from family sciences (Jaskiewicz, Combs, Shanine, \& Kacmar, 2017) and organizational behavior (Gagné, Sharma, \& De Massis, 2014) to better understand the nuances of intrafamily succession (e.g., Marler, Botero \& De Massis, 2017). Nonetheless, there is much work to be done. While family relationships are strong predictors of intrafamily succession (Morris, Williams, Allen \& Avila, 1997; Sharma, Chrisman, \& Chua, 2003), we know little about how parental behaviors influence next-generation members' motivation to engage in the family firm.

Parents face the classic roots and wings paradox, simultaneously imbuing in their offspring a feeling of belonging and the confidence to fly independently. Finding the perfect balance is a major dilemma that is further intensified when one or both parents ${ }^{1}$ also serve as family firm leaders and desire to transfer this leadership role to their progeny. Deep roots without wings cause a lack of self-confidence that binds next-generation members to the family firm as they do not believe their skills are marketable (Sharma \& Irving, 2005). But strong wings with shallow roots encourage them to fly away from their family firm (Sieger et al., 2016). This dilemma has encouraged researchers to frame succession from the founders' perspective. That is, how parent owners groom potential successors using different parenting styles (McMullen \& Warnick, 2015) or forms of parental altruism (Lubatkin, Durand, \& Ling, 2007).

\footnotetext{
${ }^{1}$ While we acknowledge family structures can vary significantly, at this early stage of theorizing, we focus on parents qua parents regardless of whether one or both may serve in the leadership role of their family business.
} 
Offspring of self-employed parents tend to feel confident about their entrepreneurial abilities (Sieger et al., 2016), but these individuals are also pessimistic about joining their parents' business due to a perceived loss of autonomy (Zellweger, Sieger, \& Halter, 2011). However, those who join their family business based on either strong identification with the firm or perceived alignment of career interests with opportunities in the business perform well and enjoy fulfilling careers (Dawson, Sharma, Irving, Marcus, \& Chirico, 2015). Their performance is even stronger when perceived family obligation drives next-generation members to join their family firm (Dawson, Irving, Sharma, Chirico, \& Marcus, 2014). This suggests family expectations serve as a strong binding force for next-generation members, positively affecting their performance. Thus, understanding the parental behaviors that influence next-generation members intentions regarding a career in their family firm requires theorizing from their perspective. In narrowing down our focus, we are steered by the rationale that individuals subjectively appraise the features of their environment, including the amount of parental support they receive (Garcia, Restubog, Toledano, Tolentino, \& Rafferty, 2012). The extent to which parental behaviors influence next-generation engagement depends on whether these individuals perceive it as beneficial or constraining, rather than simply present.

Drawing insights from the career development, organizational behavior, and family business literature, we examine next-generation engagement from the next generation's perspective. Building on the principles of social cognitive theory (Bandura, 1986) and research on organizational commitment (Meyer, Stanley, Hersovitch \& Topolnytsky, 2002), we propose that perceived parental behaviors, particularly parental support and parental psychological control, affect next-generation engagement by influencing their family business self-efficacy and commitment to the family business (Figure 1). As such, we extend prior work on self-efficacy and 
commitment in family firms (Dawson et al., 2015; Zellweger et al., 2011). Regarding self-efficacy, existing studies focus on role modeling processes as the primary mechanism of influence. Zellweger and colleagues (2011) highlight the role of observational learning as the mechanism that influences the development of entrepreneurial self-efficacy among students with a family business background. We extend their work by explaining how in addition to modeling behaviors, parents influence family business self-efficacy by being instrumental in assisting skill development, and providing emotional support and verbal encouragement. Bandura (1986) has argued that individuals base their self-efficacy judgments on a combination of these sources. We seek to understand the relationship between family business self-efficacy and engagement of next generation members. We extend prior work on commitment to next generation by building theory on how it is developed and learned from parental interactions. While Dawson and colleagues (2015) suggest antecedents of family business commitment, we extend their work by 1) clarifying how parental behaviors influence the three types of commitment (affective, normative, and continuance), and 2) explaining how each type influences the next generation's intention to engage in the family firm (as opposed to intentions to remain in the family firm).

Following Zellweger, Sieger, and Englisch (2012), next-generation engagement is defined as their (as opposed to founding or incumbent generation's) intention to actively contribute to the leadership and sustainability of their family business. This leadership may be exercised through ownership, managerial, or governance roles (Zellweger, 2017), but at this early stage of theorizing, following previous succession literature (Daspit et al., 2016), we focus on managerial leadership. We recognize that some next-generation members may participate in deviant behaviors in their family firm (Eddleston \& Kidwell, 2012), but the theory we propose aims to predict positive forms 
of next-generation engagement or those that support the family firm's long-term survival and growth. Thus, we shed light on how positive engagement develops and when it is stifled.

\section{SOCIAL COGNITIVE THEORY AND NEXT-GENERATION ENGAGEMENT}

Bandura's (1986) social cognitive theory (SCT) views human development and functioning as complex and dynamic. Behavior or intentions are perceived as a bi-product of personenvironment interactions and a predictor of person-environment factors. The behavior of interest is next generation engagement in managerial leadership of their family firm. We theorize that this behavior is affected by two attributes of these family members: their perceived self-efficacy and commitment, specifically in relation to their family firm. These attributes are influenced by the parenting environment experienced by these individuals. Before discussing our theoretical propositions, we provide an overview of the constructs in the theoretical model.

Family Business Self-Efficacy. SCT emphasizes that humans have an innate capacity to direct their own behaviors, since individuals are neither mere conduits of external forces nor fully governed by internal desires. Instead, humans have the capacity for forethought and metacognitive self-reflection (i.e., to think and reflect about thinking). The self-efficacy construct captures this self-regulative function, namely, a person's belief that s/he can successfully perform the tasks needed to meet given situational demands. Self-efficacy predicts career and performance outcomes such as career decision-making (Restubog, Florentino, \& Garcia, 2010), career choice intentions (Lent, Brown, \& Hackett, 1994), entrepreneurial intentions and behavior (Carr \& Sequeira, 2007), and work-related performance (Stajkovic \& Luthans, 1998). Individuals gravitate towards activities and careers in which they see themselves as efficacious due to their belief in a higher likelihood of achieving the desired results and their ability to persevere amidst difficulties. 
One defining feature of self-efficacy differentiating it from other self-referent constructs is its context-specific and generative nature. Self-efficacy is not a global trait, but "a differentiated set of self-beliefs linked to distinct realms of functioning" (Bandura, 2006, p. 307). Therefore, we conceptualize family business self-efficacy as next-generation members' beliefs in their ability to successfully engage in the managerial leadership of their family business. This focus differs from previous work using entrepreneurial self-efficacy to predict the intention of next-generation family members to join their family firms (Sieger et al., 2016; Zellweger et al., 2011). While some entrepreneurial skills are needed, research on attributes that are important for the success of nextgeneration members engagement suggests this context calls for a unique set of capabilities (Chrisman, Chua, \& Sharma, 1998). Taking over a family firm's leadership, next-generation members have the added responsibility of managing and maintaining both family and business relationships, gaining buy-in and support from non-family employees and other key stakeholders (DeNoble, Ehrlich, \& Singh, 2007; Tabor, Chrisman, Madison, \& Vardaman, 2018). That is, they need both formal and cultural competencies (Hall \& Nordqvist, 2008). Belief in the successor's abilities in diplomacy, conflict resolution, and negotiation are even more relevant and salient in family firms compared to non-family firms. Sieger and colleagues (2016) found that entrepreneurial motives are better predictors of entrepreneurial intention as opposed to succession intention. Indeed, they found a negative relationship between entrepreneurial self-efficacy and succession intention. Given these results, we focus on 'family business self-efficacy' as opposed to general competence or entrepreneurial self-efficacy.

Commitment to the Family Business is a highly valued attribute of next-generation family members by senior-generation leaders (Chrisman et al., 1998). Commitment is a psychological state that compels an individual toward a course of action (Meyer et al., 2002). Individuals may 
choose to work with their current employer for three propelling reasons: emotional attachment to their organization (affective commitment); a feeling of indebtedness or obligation (normative commitment); concern for work- and nonwork-related costs (continuance commitment) ${ }^{2}$.

Based on this research, we define commitment to the family business as the psychological state of mind compelling a next-generation member toward the managerial leadership of his/her family business. This pull to contribute in a managerial role is distinct from a compulsion they may feel toward their family. If primary commitment is to the family, there may be other ways to contribute beyond a managerial leadership role in the family firm, which is the focus of this article. For example, to avoid family conflicts it may be better to not engage in the business at all or at least not in a managerial role. While this may help maintain family relationships, it may not necessarily serve the family business.

Parental Behaviors. Extensive research on parent-child socialization confirms two key dimensions of parenting behaviors associated with the optimal functioning and well-being of a child. These are parental support and parental control (Barber, 2002). Conceptualized as the level of acceptance, warmth, and responsiveness that parents express toward their children, parental support is essential to the normal development of children and an important contributor to parenting styles (McMullen \& Warnick, 2015). Parental support is positively related to higher social and academic achievement, higher self-esteem, and lower depression in children and adolescents (Bean, Barber \& Crane, 2006).

Parental control has been conceptualized as regulating and disciplinary behaviors that can vary in terms of whether exercised to facilitate or hinder the child's needs and development (Barber,

\footnotetext{
${ }^{2}$ While initial family business case studies signal the presence of two separate continuance commitment dimensions (calculative and imperative), this was not evident in subsequent empirical studies (see Dawson et al., 2014). Results regarding the bi-dimensionality of continuance commitment remain inconsistent (see Meyer \& Herscovitch, 2001). As such, we focus on the more widely recognized three-component model.
} 
Stolz, Olsen, Collins, \& Burchinal, 2005). Parental control can be further classified into two types: behavioral and psychological control. Behavioral control is characterized by parental behaviors that attempt to control or manage the child's behavior, including the imposition of a regulating structure, such as parental monitoring or family management (Barber et al., 2005). This has generally been linked to positive outcomes, including lower levels of delinquency and deviance (Barber et al., 2005), and higher levels of academic performance (White \& Kaufman, 1997).

Psychological control concerns the excessive control of a domineering parent who intrudes on a child's sense of self by manipulating and constraining interactions, and invalidating choices and feelings. It includes manipulating the love relationship between parent and child, making concern and care dependent on whether the child follows the parent's wishes and demands. In the family business context, this behavior is typically driven by incumbents' desire to clone themselves in the figure of the successor (Garcia-Alvarez \& Lopez-Sintas, 2006). Psychological parental control appears to negatively affect a child's well-being by contributing to internalized problems, such as depression and anxiety (Bean et al., 2006). This occurs as it does not permit the child to develop as an individual differently from the parent (Barber, 2002), and is thus more likely to lead to grooming in a selfish manipulative way, rather than selfless transparent nurturing of next-generation members (McMullen and Warnick, 2015).

We focus on parental support and parental psychological control for two reasons. First, conceptualizations of supportive parental behavior overlap with behavioral control as it not only includes the provision of concern and affection but also entails providing structure through praise and reasoning (Turner \& Lapan, 2002). Second, disentangling parental support from parental psychological control may help explain inconsistencies in how parental behaviors influence nextgeneration engagement. Parental involvement may be beneficial and necessary for succession, but 
may constitute unwelcome interference suppressing normal adolescent development (Kaye, 1996). Most conceptualizations of parental control refer to behavioral control or assume that both forms of control are the same (Barber, 1996). We focus on psychological control, as much less attention has been devoted to understanding how this influences next-generation behaviors (Bean et al., 2006).

\section{(Insert Figure 1 about here)}

\section{Perceived Parental Behaviors, Family Business Self-Efficacy, Commitment to the Family Business, and Next-Generation Engagement in Family Firms}

Entrepreneurship research acknowledges the significant role parents play in shaping the credibility and desirability of an entrepreneurial career in their children's minds (Fairlie \& Robb, 2007). Behavioral research from an SCT perspective shows that as primary providers of resources and socio-emotional support, parents are highly influential during a child's formative years (Restubog et al., 2010). Due to their direct interaction as providers in their lives, children often view parents as sources of guidance and advice (Turner \& Lapan, 2002). But exactly how do parents influence next-generation engagement? What specific parental behaviors are effective in increasing the self-efficacy and commitment of next-generation members toward their family firm?

Parental Support and Family Business Self-efficacy. According to Turner and Lapan (2002), the four types of parental support that increase self-efficacy beliefs are instrumental assistance, career-related modeling, verbal encouragement, and emotional support. Instrumental assistance involves behaviors that assist children's and adolescents' career-related skill development. In a family business context, this entails behaviors such as providing successors with opportunities to gain work experience through apprenticeships and financial assistance for formal education or 
professional development (Zhao, Seibert, \& Hills, 2005). Indeed, formal education influences post-transition performance and the promotability of family firm successors (Morris et al., 1997).

Parents can also increase their children's self-efficacy through career-related modeling where potential successors learn through observational learning. The effectiveness of this learning mode depends on whether the observed role model attains positive outcomes also relevant to the successor. Individuals who perceived parents to be successful entrepreneurs have a higher likelihood of establishing a new venture as opposed to those not exposed to successful role models (Fairlie \& Robb, 2007). Potential successors are also more likely to engage in the family business if they can follow the example of role models they admire (Zellweger et al., 2012).

Verbal encouragement on specific performance feedback from trusted others helps sustain a sense of efficacy, especially during challenging situations. However, verbal encouragement should be realistic to avoid instances of overconfidence (Boyd \& Vozikis, 1994). Praise and recognition not tied to real accomplishments may send the message that minimal effort is praiseworthy and sufficient (Bandura, 1986). In addition, next-generation members are often verbally encouraged to join the firm (Litz, 2012). Indeed, parental encouragement and a positive attitude to the family business are critical in developing leadership interest in the family business (Handler, 1990).

Lastly, parents can increase self-efficacy through emotional support, particularly influencing children's affective reactions toward participation in the family business. Helping potential successors manage negative emotions is especially important in the family business context where the family and the firm are inextricably linked (Zellweger \& Dehlen, 2012). That is, successors may suffer from fear or anxiety arising from the need to differentiate themselves from incumbents as they exert their own personal identities (Dunn, 1999). Indeed, positive reactions toward 
children's entrepreneurial aspirations lead to higher succession intention (Zellweger, 2017). Hence, we propose that:

Proposition 1: Perceived parental support, in the form of instrumental assistance, careerrelated modeling, verbal encouragement, and emotional support, is positively related to nextgeneration members' family business self-efficacy.

Parental Support and Commitment to the Family Business. We also propose that parental support shapes the type of commitment of next-generation members toward the family firm. Our propositions for this relationship derive from commitment research in family firms (Sharma \& Irving, 2005) and organizational behavior literature where commitment has mainly been studied in employer-employee relationships (Van Knippenberg \& Sleebos, 2006). Organizational commitment is predicted both by job characteristics and the quality of the exchange relationship between the individual and organizational members, such as colleagues and supervisors (Van Knippenberg \& Sleebos, 2006), as well as family members, particularly senior generation incumbent leaders (Dawson et al., 2014; 2015). Perceived organizational support (POS) is strongly and positively correlated with affective commitment, as it signals to employees that the organization values their contributions and cares about their well-being (Rhoades \& Eisenberger, 2002). POS helps address employees' socio-emotional needs, such as esteem, approval, and affiliation (Shore \& Tetrick, 1991). When this occurs, employees develop a deeper sense of belonging and pride toward the organization, manifested in higher levels of affective commitment. In family firms, parental support similarly addresses next-generation members' socio-emotional needs (Ceja-Barba, 2014). Through instrumental assistance and career-related modeling, seniorgeneration family members provide opportunities for next-generation members to enhance their skills in managing the family firm. In particular, internships or apprenticeships socialize next- 
generation members to the family firm's goals and values. This increases affective commitment, as they perceive an alignment of their identity with the needs, goals, and values of their family business (Dawson et al., 2015). Through verbal encouragement and emotional support, parent incumbents can convey trust in the successors' capabilities which further enhances their emotional attachment to the family firm. Indeed, supporting next-generation members fosters a feeling they are important and valuable members of the family firm (Memili, Zellweger, \& Fang, 2013). Thus:

Proposition 2a: Perceived parental support, in the form of instrumental assistance, careerrelated modeling, verbal encouragement, and emotional support, is positively related to nextgeneration members' affective commitment toward the family business.

Parental support can also increase next-generation members' normative commitment toward the family business. This relationship can be explained by the norm of reciprocity (Gouldner, 1960), that is, we repay in kind what others have done for us. Thus, when next-generation members perceive that their parents show concern about their career development and well-being, they are more likely to feel indebted to them. One way to reciprocate is to work in the family firm to carry forward the legacy of their parents. As with affective commitment, we expect the four forms of parental support to increase normative commitment towards the family firm. The difference lies with whether parental support is given as a means to increase emotional attachment to the family firm (affective commitment) or primarily as means to reinforce expectations of reciprocity (normative commitment). Indeed, family expectations significantly predict next-generation members' obligation to remain in the family firm (Dawson et al., 2015). Thus:

Proposition 2b: Perceived parental support, in the form of instrumental assistance, careerrelated modeling, verbal encouragement, and emotional support, is positively related to nextgeneration members' normative commitment toward the family business. 
High levels of perceived support are either unrelated or negatively related to continuance commitment (Aubé, Rousseau, \& Morin, 2007). Next-generation family members with high levels of continuance commitment engage in the family business because of the social or financial costs associated with non-engagement. Effective parental support should reduce next-generation members' feelings of entrapment, as this should serve to address the child's socio-emotional needs (Garcia et al., 2012). As discussed above, provision of parental support promotes positive attitudes towards the family firm which should lead to a greater sense of alignment with the family firm as opposed to feelings of entrapment. After all, parental support is manifested not just in the provision of financial or economic resources, but also includes verbal encouragement and emotional support, relating to a more affective than economic exchange relationship. Thus:

Proposition 2c: Perceived parental support, in the form of instrumental assistance, careerrelated modeling, verbal encouragement, and emotional support, is negatively related to nextgeneration members' continuance commitment toward the family business.

Parental Psychological Control and Family Business Self-Efficacy. As parents try to balance the needs of several claimants of rewards (including their own legacy desires), their involvement may be manifested through extreme control (Dietrich \& Kracke, 2009). By virtue of the power they have over resources, parents can exert unwanted influence, controlling their children's career interests and choices (Schultheiss, Kress, Manzi, \& Glasscock, 2001). Parental control interferes with the child's individuation, restricting adolescents' decision-making and autonomy (Kaye, 1996). This then leads to fewer opportunities for self and environmental exploration, both essential ingredients to developing high levels of self-efficacy (Garcia et al., 2012). Parental control is particularly relevant in family firms due to the close interface between family and the business (Habbershon, Williams, \& MacMillan, 2003). Incumbents may focus on 
preserving the wealth and power associated with the family business at the expense of the adaptive development of their children (Kaye, 1996). As Le Breton-Miller and Miller (2014, p. 671) note, controlling and domineering incumbent parents tend to have offspring who "worship them, lack independence of thought and confidence, and to slavishly copy their parents' practices even after these had lost relevance". Psychological control undermines family business self-efficacy as it hinders development of personal standards important in forming self-efficacy judgments (Bandura, 1986). As acceptance and affection are contingent on avoiding failure, this breeds successors who focus on pleasing their parents as opposed to developing their sense of competence (Givertz \& Segrin, 2014). As such, these next-generation members may interpret failure more as a sign they are unworthy successors as opposed to an opportunity from which they can learn. Thus:

Proposition 3: Perceived parental psychological control is negatively related to nextgeneration members' family business self-efficacy.

Parental Psychological Control and Commitment to the Family Business. In the context of family firms, we lack examination of the relationship between parental psychological control and family members' commitment toward their firm. We expect this relationship to vary depending on type of successor commitment predicted. We draw parallels from organizational behavior literature on parent-child and supervisor-subordinate relationships to guide our propositions (Game, 2008). Similar to abusive and destructive leadership, parental psychological control also involves domineering and manipulative behaviors geared to exploiting the relationship between the parent and the child. Unfair treatment by supervisors reduces affective commitment and increases withdrawal behavior (Colquitt, Conlon, Wesson, Porter, \& Ng, 2001). Similarly, parental psychological control may lead next-generation members to interpret that the incumbent parent does not value their contributions to the family business. Further, psychological control can result 
in conflicts as next-generation members try to shift the balance of power by rebelling against their parents' desires (Lubatkin et al., 2007). This can damage family harmony, an essential ingredient for the development of affective commitment, especially in family firms (Memili et al., 2013). Moreover, psychologically controlling parents pressure children to comply with their own personal standards and needs, irrespective of children's needs and values (Schröder \& Schmitt-Rodermund, 2013), weakening next-generation members' emotional attachment to the family firm. Thus:

Proposition 4a: Perceived parental psychological control is negatively related to nextgeneration members' affective commitment toward the family business.

Conversely, we expect parental psychological control to increase both normative and continuance commitment. Controlling behaviors may increase feelings that children are "obligated" to reciprocate the investment their parents have made in them. Indeed, strong family expectations significantly increase normative commitment toward the family firm (Dawson et al., 2015). As Lubatkin and colleagues (2007) suggest, domineering parental behavior is driven by expectations of requited generosity. Through psychological control, children are socialized to expect that the resources they receive need to be repaid. Similarly, we expect parental psychological control to increase continuance commitment toward the family firm. Such control involves limiting the independence and autonomy of next-generation members, preventing them from exploring alternative career paths. Limited exploration of alternative career paths induces risk and uncertainty, increasing the "costs" associated with pursuing careers outside the family firm (Dawson et al., 2015). Further, controlling parents may increase economic and social costs associated with leaving the family firm by offering financial rewards or highlighting the risk of ostracism (Nicholson, 2015). Thus, incumbents may use their power over important resources that 
the potential successor values to increase the perceived costs of not engaging in the family business. Thus:

Proposition 4b: Perceived parental psychological control is positively related to nextgeneration members' normative commitment toward the family business.

Proposition 4c: Perceived parental psychological control is positively related to nextgeneration members' continuance commitment toward the family business.

Family Business Self-Efficacy, Commitment, and Next-generation Engagement. Selfefficacy influences an individual's intention to engage in particular activities. People will generally choose tasks or goals congruent with their self-efficacy beliefs (Bandura, 1986). Thus, selfefficacy beliefs are the primary drivers of motivated action. Self-efficacy for technical/scientific fields is positively related to perceived career options in technical/scientific fields, and this relationship remains significant after controlling for interest (Lent, Brown, \& Larkin, 1986). Similarly, entrepreneurial self-efficacy increases entrepreneurial intentions and behavior (Sieger et al., 2016; Zellweger et al., 2011). Specifically, entrepreneurial self-efficacy mediates the relationship between perceived family support and entrepreneurial intent (Carr \& Sequeirra, 2007). Thus:

Proposition 5: Next-generation members' family business self-efficacy is positively related to their engagement in the family business.

We also expect all three types of commitment (affective, normative, and continuance) to increase next-generation intentions to engage in the family business. High levels of affective commitment indicate that next-generation members' sense of self and identity are aligned with family firm goals and values (Dawson et al., 2015). Further, next-generation members high in affective commitment are more likely to go beyond contractual duties and responsibilities to 
achieve family business goals (Dawson et al., 2014). Similarly, we expect next-generation members high in normative commitment to have high intentions to engage in the family business. The sense of obligation to the family firm is not necessarily negative as "individuals may feel a sense of satisfaction if they meet the expectations of other family members maintaining positive social relations with these significant people" (Dawson et al., 2014, p. 3). Indeed, these authors found that only normative commitment is predictive of transformational leadership among family firms. In organizational behavior research, continuance commitment has the weakest influence on turnover intentions and actual turnover (Meyer et al., 2002). As our outcome variable focuses on the intention of next-generation members to engage in managerial leadership of their family business, as opposed to whether they would stay or perform well in the job, we expect a positive relationship between continuance commitment and next-generation engagement. Next-generation members with high levels of continuance commitment perceive stong costs associated with seeking alternative career paths, leading to working in the family business as the "default" career path (Dawson et al., 2015). Thus:

Proposition 6: Next-generation members' affective, normative, and continuance commitment is positively related to their engagement in the family business.

\section{DISCUSSION}

A major concern of family businesses worldwide is unwillingness of next-generation members to engage in the family business. We propose that two types of parental behaviors - support and psychological control - influence next-generation members' desire to engage in the managerial leadership role of their family firm. This influence is indirect as these parental behaviors are 
appraised by next-generation members and form the basis of their efficacy beliefs and commitment towards the family firm.

We contribute to research on family dynamics and succession intentions in several ways. First, while studies recognize the important role of parent-child relationships in shaping family business competence and commitment (Lubatkin et al., 2007), most focus on broad and aggregated conceptualizations of parental influence. For instance, McMullen and Warnick (2015) suggest that based on the extent of accountability expected from children and responsiveness toward their psychological needs, parents may adopt one of four parenting styles - neglectful, indulgent, authoritarian, and authoritative. As a constellation of attitudes, parenting styles provide the context and emotional backdrop for child rearing (Darling \& Steinberg, 1993). We extend prior work by theorizing on the effects of more fine-grained and specific forms of parental influence. This conceptualization offers two advantages. First, parental styles do not distinguish between the two types of parental control, behavioral vs. psychological, which differently influence children's behavior (Barber et al., 2005). It would thus be difficult to identify the unique effects of parental behaviors on next-generation engagement if we followed an aggregate typological approach. Second, social norms and culture play a role in the perceived appropriateness of parental styles. The extent to which authoritarian parenting is endorsed varies according to culture (Rudy \& Grusec, 2006). Focusing on parental behaviors as opposed to parental styles allows us to hypothesize relative effects without making assumptions on the best configuration for a given context or culture.

Second, we address calls for alternative theoretical perspectives that explain succession at the individual-level of analysis (Daspit et al., 2016). Specifically, we draw on SCT to examine parental behaviors, self-efficacy, and commitment from next-generation members' perspective. Our 
propositions recognize that family business self-efficacy and commitment derive from how successors appraise their parenting environments, complementing perspectives based on current leaders' parenting or mentoring styles in previous conceptualizations (McMullen \& Warnick, 2015).

Third, by showing that attributes of next-generation members and the behaviors of their parents affect next-generation engagement in family firms, we contribute to research arguing that the succession process is influenced by the characteristics of the individuals involved (Le BretonMiller, Miller, \& Steier, 2004). Our theory complements family business studies on the role of incumbents in the succession process (De Massis, Chua, \& Chrisman, 2008; Le Breton-Miller et al., 2004) and on the determinants of potential successors' intention to take over the family business leadership (Zellweger et al., 2011). This should help researchers and practitioners develop a fuller understanding of the two intentions that must exist for intrafamily succession to occur (De Massis et al., 2008): the incumbent's intention to hand over leadership to the next generation and the successor's intention to take over. As such, our study contributes conceptually to the development of a theory of the family firm, since next-generation engagement, through its influence on intrafamily succession intention, could explain the divergence between family and non-family firms, and heterogeneity among family firms (Chua, Chrisman, Steier, \& Rau, 2012). Moreover, our model adds to frameworks proposed to describe the process-oriented nature of family business succession (Le Breton-Miller et al., 2004; Royer, Simons, Boyd, \& Rafferty, 2008) by exploring not just the "what" of intrafamily succession but also the "why" of the intention of next-generation members to engage in the family business. Finally, by shedding nuanced light on drivers of next-generation members' intention to engage in the family firm, we contribute to 
growing research on factors that affect the choice of family-internal and family-external exit routes (Dehlen, Zellweger, Kammerlander, \& Halter, 2014).

Our framework provides several avenues for future research relating to the appropriateness of parental support in the context of family firms and contingency factors.

Parental Behaviors in the Family Business Context. While numerous studies found positive outcomes associated with perceived parental support, these tend to be based on contexts where, presumably, adolescents are afforded autonomy in how they develop their career-related interests (Garcia, Restubog, Bordia, Bordia, \& Roxas, 2015; Restubog et al., 2010). The family business context in general, and succession planning in particular, present unique issues that may render parental support inappropriate, or worse, unethical (Kaye, 1996). Should parents actively engage in supportive behaviors geared toward enhancing family business self-efficacy and commitment toward the family business during formative years or should they allow career interests to develop freely? As parental support will likely only lead to beneficial outcomes if the family business addresses the successor's need for competence, autonomy, and relatedness (McMullen \& Warnick, 2015), the answer depends on the purpose of the provision of parental support. To be effective, parental support needs to be influential, not simply permissive or neglectful (Lubatkin et al., 2007). This underscores the importance of distinguishing between behavioral and psychological control, as we highlight. Some degree of behavioral control is needed for individuation. On the contrary, psychological control, which involves emotional manipulation as the primary means of parental involvement, is likely highly detrimental to adolescent differentiation (Barber, 1996). Note, though, that the perceived appropriateness of parental support and control also depends on the norms of the larger society in which it operates (Lubatkin et al., 2007). Successors also interpret the amount of support and control they receive based on what they think is "socially acceptable". 
Further, as our propositions are centered on the influence of parental support and psychological control, it would be fruitful to explore the relative effect of behavioral control on next-generation engagement. As behavioral control is linked to higher levels of competence (White \& Kaufmann, 1997), we expect that it would also have a positive effect on self-efficacy, similar to parental support. However, there is less theoretical clarity on how behavioral control may influence the three dimensions of commitment, which constitutes an avenue for future research.

Our theoretical framework assumes that all family firms have the intention for intra-family succession, consistent with the family business literature (Chua et al., 1999). The intention for intra-family succession is indeed important to distinguish family firm behavior from that of firms with concentrated ownership (De Massis, Sharma, Chua, \& Chrisman, 2012). Another area ripe for future research is extending our proposed theory to situations where the owning family is not oriented to handing over the business to the next generation.

Finally, our proposed model does not directly take into account the possible influence of parental differential treatment (PDT) of siblings or misalignment of treatment toward a next generation member by different parents, probably influenced by whether they are active in the business or not. However, we recommend that future work explores these untested propositions. Indeed, evidence exists that parents may afford their children varying degrees of closeness, support, and control (Suitor, Sechrist, Plikuhn, Pardo, \& Pillemer, 2008). Differential treatment is associated with greater behavior problems for less-favored siblings (Suitor et al., 2008). In studying the possible effects of PDT in family firms, it is important to consider whether siblings deem preferential treatment necessary or justified (Friedman, 1991). A child might think it is "acceptable" for their sibling to receive more attention if this is warranted based on the latter's developmental needs. 
Another issue worth noting is the rise of "non-traditional families" where the number of divorces, stepfamilies, and extramarital births is higher, couples are less frequently tied by marriage, and the number of children drops (Bengtson, 2001). The presence of stepchildren or extramarital births may lead to situations where there are multiple potential successors, some of whom may not have blood ties and/or be raised by the owners of the family firm. This could complicate the relationship between parents and next-generation members by further dividing support and control, potentially resulting in conflictual or competitive relationships among nextgeneration members (Friedman, 1991). Future research could examine how these changes influence the proposed relationships in our model. That is, studies should take into account the heterogeneity of different family systems in terms of family structures, functions, relationships, and events (Jaskiewicz \& Dyer, 2017; Jaskiewicz et al., 2017).

Temporal contingencies and considerations. A theoretical extension of our model is exploring the temporal contingency of parental behavior on next-generation engagement, that is, the influence of family ownership duration defined as the length of time that family owners have been in control of the firm (Zellweger et al., 2012). Existing literature emphasizes the importance of considering temporal aspects in studying family firms (Sharma, De Massis, \& Gagnè, 2014; Sharma, Salvato, \& Reay, 2013). The time-variant nature of family ownership and its organizational consequences are recognized (Zellweger et al., 2012), and a temporal perspective helps shed light on the different forms that family ownership can take and the ensuing differences in next-generation engagement over time.

Emotional attachment to possessions generally follows a psychological appropriation process, such that possession of an asset gradually becomes part of the owner's identity (Belk, 1988). Over time, existing routines and beliefs become part of the family owners' legacy and symbolize their 
continuity, increasing later-generations' perceived value of the assets beyond their financial value (Zellweger et al., 2012). Similarly, family owners likely increase their psychological attachment to existing knowledge assets with time. As a result, the goal dimension of family ownership influence should increase over time, strengthening the effects of parental support and control over the firm's lifetime. Specifically, the positive influence of parental support and the negative influence of parental psychological control on next-generation members' beliefs in their ability to successfully engage in managerial leadership of their family business are likely stronger over time as the goal dimension of the influence of family ownership increases.

However, family ownership influence through power concentration may weaken over time, as a longer association between the owner and non-family members fosters family trust toward these members, supporting participation in decision-making processes (Patel \& Cooper, 2014) and reducing the distance between upper echelons and the rest of the organization (Verbeke \& Kano, 2012). This reduction in power concentration may reduce the positive effect of parental support and control on next-generation engagement over time. Specifically, the positive influence of parental support and the negative influence of parental control on family business self-efficacy likely weaken over time as the power dimension of the influence of family ownership decreases.

Finally, the proposed model could be expanded to include the actual job performance of nextgeneration individuals on family and business dimensions given the diversity of family business goals (Kotlar \& De Massis, 2013; Chua et al., 2018). Such an extension could be focused on understanding the contextual performance and leadership effectiveness of these individuals, thereby building on previous commitment research (Dawson et al., 2014). 
Model Testing. In considering how the proposed theoretical model may be empirically tested we pay particular attention to possible scales that could be used as well as highlighting potential measurement and research design issues that need to be addressed.

The family science and careers literature offers potential scales to measure parental behaviors. Barnes and Farrel (1992) propose an 8-item scale to measure parental support by assessing adolescents' perceptions of their parents' behaviors, such as praising, encouraging, and physical affection, which indicate to the adolescent that he or she is accepted and supported. Another scale that can be adapted to measure parental support is that of Turner, Alliman-Brissett, Lapan, Udipi, and Ergun (2003). The advantage of this scale is that parental support is conceptualized in relation to the four sources of self-efficacy information reflected in four subscales: parental instrumental assistance, career-related modeling, verbal encouragement, and emotional support. Barber (1996) reports useful scales to measure parental psychological control. Specifically, future scholars could use the 10-item psychological control scale from the revised Children's Report of Parental Behavior Inventory (CRPBI) (Schaefer, 1965; Schludermann \& Schludermann, 1970) to measure components of parental psychological control, such as guilt induction, love withdrawal, and excessive pressure for change. Ideally, scholars would combine self-reported measures with observational measures of psychological control. Barber (1996) uses the Family Process Code (Dishion, Gardner, Patterson, Reid, \& Thibodeaux, 1983), a micro social coding system that records family interaction in real time, capturing the content and affective valence of the interaction. It codes parent-child interactions and measures behavioral control by using a composite variable consisting of coder impressions on monitoring, limit setting, relationship quality, problem solving, and positive reinforcement. 
Items used in an all-purpose self-efficacy test may have little or no relevance to the domain of focus in a particular study (Bandura, 2006). We lack family business domain-specific measures of self-efficacy, as most studies rely on entrepreneurial self-efficacy (Zellweger et al., 2011). DeNoble et al. (2007) offer guidance on how to modify existing entrepreneurial self-efficacy scales for their greater applicability in the family business context. For instance, items in the entrepreneurial self-efficacy scale of Chen, Green \& Crick (1998) can be supplemented with additional items related to managing family and stakeholder relationships, skills particularly important in the effective leadership and management of family firms (DeNoble et al., 2007). As for family business commitment, the scale of Allen and Meyer (1990) has been modified for use in family firms (Dawson et al., 2015).

Researchers should proceed with caution in using these scales as they were not developed to specifically assess constructs in a family business context. We have focused on theorizing the behavior of parents qua parents. However, the behavior of parents whether or not active in the family business may or may not be aligned. Future research needs to consider the development of instruments to capture perceived differences in the behavior of active and non-active parents, for example by asking separate sets of questions for each parent. Moreover, existing measures for parental support usually include items pertaining to how parents support general career development tasks, such as career exploration, helping with homework, general career advice (Turner et al., 2003). While these behaviors can apply in family business contexts, they do not represent other means by which parent-incumbents influence their children. For example, general parental support measures focus on provisions for formal education. However, apprenticeship and opportunities to work for the family firm may be particularly relevant to developing family business efficacy and commitment (Houshmand, Seidel, \& Ma, 2017). These scales can be 
modified, but this should be supported with evidence of the modified scale's psychometric properties.

Our model could be empirically extended using multi-level research designs to examine how group-level variables, such as senior family members or extended family definitions, influence self-efficacy and commitment. Alternatively, family-level collective self-efficacy might also play a role in shaping individual-level self-efficacy and commitment (Bandura, Caprara, Barbaranelli, Regalia, \& Scabini, 2011). Longitudinal research designs would be helpful in terms of capturing temporal and dynamic aspects underlying the relationships in our model. We recommend measuring elements of the model repeatedly to allow researchers to model change over time, obtain valid estimates, and enhance predictions about the causal direction of the proposed relationships. Using time lags, self-efficacy and next-generation engagement could be measured over a period of time. Controlling for autoregressive paths (e.g., the relation of next-generation engagement at Time 1 with next-generation engagement at Time 2) and modeling paths from Time 1 self-efficacy to Time 2 next-generation engagement, and from Time 1 next-generation engagement to Time 2 self-efficacy, would allow researchers to assess the temporal ordering of these variables. It also allows for examination of successors' persistence over time (i.e., whether they stay in or leave the family firm after succession). A longitudinal research design could also test the plausible bidirectional relationship between next-generation engagement and parental behaviors. Support for this notion exists in that adolescents who work for the family firm have better relationships with their parents compared to those who work elsewhere (Houshmand et al., 2017). This could suggest that next-generation members who decide to work for the family firm may elicit higher levels of parental support, which creates a feed-back loop mechanism.

\section{CONCLUSION}


Failure to engage the next generation could put family business continuity at risk. Despite the intention and desire of current-generation leaders to continue the family business and 'pass the baton', less than $7 \%$ of rising-generation members are willing to take over the firm (Sieger et al., 2016; Zelleweger et al., 2012). The looming succession crisis makes it important to understand the factors that influence the engagement of the next generation in their family firms. We have proposed a theoretical model that focused on the next-generation's perceptions and perspective. That is, next-generation members appraise how they are treated by their parents and this in turn shapes their beliefs about their competence and their attitudes towards the family firm. We hope that the ideas presented in this paper will encourage future work to further examine the cognitive, motivational, and behavioral aspects of next-generation engagement in family firms.

\section{REFERENCES}

Allen, N.J., \& Meyer, J.P. (1990). The measurement and antecedents of affective, continuance and normative commitment to the organization. Journal of Occupational and Organizational Psychology, 63, 1-18.

Aubé, C., Rousseau, V., \& Morin, E.M. (2007). Perceived organizational support and organizational commitment: The moderating effect of locus of control and work autonomy. Journal of Managerial Psychology, 22, 479-495.

Bandura, A. (1986). Social foundations of thought and action. Englewood Cliffs, NJ: PrenticeHall.

Bandura, A. (2006). Guide for constructing self-efficacy scales. In F. Pajares \& T. Urdan (Eds.), Self-efficacy beliefs of adolescents (pp. 307-337). Greenwich, CA: Information Age Publishing.

Barber, B.K. (1996). Parental psychological control: Revisiting a neglected construct. Child Development, 67, 3296-3319.

Barber, B.K. (2002). Intrusive parenting: How psychological control affects children and adolescents. Washington, DC: American Psychological Association. 
Barber, B.K., Stolz, H.E., Olsen, J.A., Collins, W.A., \& Burchinal, M. (2005). Parental support, psychological control, and behavioral control: Assessing relevance across time, culture, and method. Monographs of the Society for Research in Child Development, i-147.

Barnes, G.M., \& Farrell, M.P. (1992). Parental support and control as predictors of adolescent drinking, delinquency, and related problem behaviors. Journal of Marriage and the Family, 763-776.

Bean, R.Y., Barber, B.K., \& Crane, D.R. (2006). Parental support, behavioral control, and psychological control among African American Youth. Journal of Family Issues, 27, 1335-1355.

Belk, R.W. (1988). Possessions and the extended self. Journal of Consumer Research, 15, 139168.

Bengtson, V.L. (2001). Beyond the nuclear family: The increasing importance of multigenerational bonds. Journal of Marriage and Family, 63, 1-16.

Boyd, N.G., \& Vozikis, G.S. (1994). The influence of self-efficacy on the development of entrepreneurial intentions and actions. Entrepreneurship Theory and Practice, 18, 63-63.

Carr, J.C., \& Sequeira, J.M. (2007). Prior family business exposure as intergenerational influence and entrepreneurial intent: A theory of planned behavior approach. Journal of Business Research, 60, 1090-1098.

Ceja-Barba, L. (2014). Towards a positive organizational study of family-owned businesses: Embracing a fertile territory. European Journal of Work and Organizational Psychology, 23, 665-668.

Chen, C. C., Greene, P. G., \& Crick, A. (1998). Does entrepreneurial self-efficacy distinguish entrepreneurs from managers? Journal of Business Venturing, 13, 295-316.

Chrisman, J.J., Chua, J.H., \& Sharma, P. (1998). Important attributes of successors in family businesses: An exploratory study. Family Business Review, 11, 19-34.

Chua, J.H., Chrisman, J.J., De Massis, A., \& Wang, H. (2018). Reflections on family firm goals and the assessment of performance. Journal of Family Business Strategy. In press.

Chua, J.H., Chrisman, J.J., \& Sharma, P. (1999). Defining the family business by behavior. Entrepreneurship Theory and Practice, 23, 19-19.

Chua, J.H., Chrisman, J.J., Steier, L.P., \& Rau, S.B. (2012). Sources of heterogeneity in family firms: An introduction. Entrepreneurship Theory and Practice, 36, 1103-1113. 
Colquitt, J.A., Conlon, D.E., Wesson, M.J., Porter, C.O., \& Ng, K.Y. (2001). Justice at the millennium: A meta-analytic review of 25 years of organizational justice research. Journal of Applied Psychology, 86, 425-445.

Darling, N., \& Steinberg, L. (1993). Parenting style as context: An integrative model. Psychological Bulletin, 113(3), 487-496.

Daspit, J.J., Holt, D.T., Chrisman, J.J., \& Long, R.G. (2016). Examining family firm succession from a social exchange perspective: A multiphase, multi-stakeholder review. Family Business Review, 29, 44-64.

Dawson, A., Irving, P.G., Sharma, P., Chirico, F., \& Marcus, J. (2014). Behavioral outcomes of next-generation family members' commitment to their firm. European Journal of Work and Organizational Psychology, 23, 570-581.

Dawson, A., Sharma, P., Irving, P.G., Marcus, J., \& Chirico, F. (2015). Predictors of latergeneration family members' commitment to family enterprises. Entrepreneurship Theory and Practice, 39, 545-569.

Dehlen, T., Zellweger, T., Kammerlander, N., \& Halter, F. (2014). The role of information asymmetry in the choice of entrepreneurial exit routes. Journal of Business Venturing, 29, 193209.

De Massis, A., Chua, J.H., \& Chrisman, J.J. (2008). Factors preventing intra-family succession. Family Business Review, 21, 183-199.

De Massis, A., Kotlar, J., Chua, J.H., \& Chrisman, J. (2014). Ability and willingness as sufficiency conditions for family-oriented particularistic behavior: Implications for theory and empirical studies. Journal of Small Business Management, 52, 344-364.

De Massis A., Sharma P., Chua J.H., and Chrisman J.J. (2012). Family business studies: An annotated bibliography. Edward Elgar, Cheltenham Glos, UK.

De Massis, A., Sieger, P., Chua, J.H., Vismara, S. (2016). Incumbents' attitude toward intrafamily succession: An investigation of its antecedents. Family Business Review, 29, 278-300.

DeNoble, A., Ehrlich, S., \&Singh, G. (2007). Toward the development of a family business selfefficacy scale: A resource-based perspective. Family Business Review, 20, 127-140.

Dietrich, J., \& Kracke, B. (2009). Career-specific parental behaviors in adolescents' development. Journal of Vocational Behavior, 75, 109-119. 
Dishion, T.J., Gardner, K., Patterson, G.R., Reid, J.B., \& Thibodeaux, S. (1983). The family process code: A multidimensional system for observing family interaction. Unpublished coding manual. Available from Oregon Social Learning Center, 207.

Dunn, B. (1999). The family factor: The impact of family relationship dynamics on businessowning families during transitions. Family Business Review, 12, 41-57.

Eddleston, K.A., \& Kidwell, R.E. (2012). Parent-child relationships: Planting the seeds of deviant behavior in the family firm. Entrepreneurship Theory and Practice, 36, 369-386.

Fairlie, R.W., \& Robb, A. (2007). Families, human capital, and small business: Evidence from the characteristics of business owners survey. Industrial and Labor Relations Review, 60, 225-245.

Friedman, S.D. (1991). Sibling relationships and intergenerational succession in family firms. Family Business Review, 4, 3-20.

Gagné, M., Sharma, P., \& De Massis, A. (2014). The study of organizational behaviour in family business. European Journal of Work and Organizational Psychology, 23, 643-656.

Game, A.M. (2008). Negative emotions in supervisory relationships: The role of relational models. Human Relations, 61, 355-393.

Garcia-Alvarez, E., \& Lopez-Sintas, J. (2006). Founder-successor's transition: a model of coherent value transmission paths. pp. 237-252. In Handbook of research on family business. Eds. P. Poutziouris, K. Smyrnios \& S. Klein. Cheltenham: Edward Elgar.

Garcia, P.R.J.M., Restubog, S.L.D., Bordia, P., Bordia, S., \& Roxas, R.E.O. (2015). Career optimism: The roles of contextual support and career decision-making self-efficacy. Journal of Vocational Behavior, 88, 10-18.

Garcia, P.R.J.M., Restubog, S.L.D., Toledano, L.S., Tolentino, L.R., \& Rafferty, A.E. (2012). Differential moderating effects of student-and parent-rated support in the relationship between learning goal orientation and career decision-making self-efficacy. Journal of Career Assessment, 20, 22-33.

Givertz, M., \& Segrin, C. (2014). The association between overinvolved parenting and young adults' self-efficacy, psychological entitlement, and family communication. Communication Research, 41, 1111-1136.

Gouldner, A.W. (1960). The norm of reciprocity: A preliminary statement. American Sociological Review, 161-178. 
Habbershon, T.G., Williams, M., \& MacMillan, I.C. (2003). A unified systems perspective of family firm performance. Journal of Business Venturing, 18, 451-465.

Hall, A., \& Nordqvist, M. (2008). Professional management in family businesses: Toward an extended understanding. Family Business Review, 21, 51-69.

Handler, W.C. (1990). Succession in family firms: A mutual role adjustment between entrepreneur and next generation family members. Entrepreneurship Theory and Practice, 15, 37-51.

Houshmand, M., Seidel, M., \& Ma, D.G. (2017). The impact of adolescent work in family business on child-parent relationships and psychological well-being. Family Business Review, 30, 242261.

Jaskiewicz, P., Combs, J.G., Shanine, K.K., \& Kacmar, K.M. (2017). Introducing the family: A review of family science with implications for management research. Academy of Management Annals, 11, 309-341.

Jaskiewicz, P., \& Dyer, W.G. (2017). Addressing the elephant in the room: Disentangling family heterogeneity to advance family business research. Family Business Review, 30, 111-118.

Kaye, K. (1996). When family business is a sickness. Family Business Review, 9, 347-368.

Kotlar, J. \& De Massis, A. (2013). Goal setting in family firms: Goal diversity, social interactions, and collective commitment to family-centered goals. Entrepreneurship Theory \& Practice, 1263-1288.

Le Breton-Miller, I., \& Miller, D. (2014). Temporal considerations in the study of family firms: Reflections on "the study of organizational behaviour in family business". European Journal of Work and Organizational Psychology, 23, 669-673.

Le Breton-Miller, I., Miller, D., \& Steier, L.P. (2004). Toward an integrative model of effective FOB succession. Entrepreneurship Theory and Practice, 28, 305-328.

Lent, R.W., Brown, S.D., \& Hackett, G. (1994). Toward a unifying social cognitive theory of career and academic interest, choice, and performance. Journal of Vocational Behavior, 45, 79122 .

Lent, R.W., Brown, S.D., \& Larkin, K.C. (1986). Self-efficacy in the prediction of academic performance and perceived career options. Journal of Counseling Psychology, 33, 265.

Litz, R.A. (2012). Double roles, double binds? Double bind theory and family business research. In Understanding family businesses (pp. 115-132). New York: Springer. 
Lubatkin, M.H., Durand, R., \& Ling, Y. (2007). The missing lens in family firm governance theory: A self-other typology of parental altruism. Journal of Business Research, 60, 10221029.

Marler, L., Botero I., \& De Massis, A. (2017). Succession-related role transitions in family firms: The impact of proactive personality. Journal of Managerial Issues, 24, 57-81.

McMullen, J.S., \& Warnick, B.J. (2015). To nurture or groom? The parent-founder succession dilemma. Entrepreneurship Theory an Practice, 39, 1379-1412.

Memili, E., Zellweger, T.M., \& Fang, H.C. (2013). The determinants of family owner-managers' affective organizational commitment. Family Relations, 62, 443-456.

Meyer, J.P., \& Herscovitch, L. (2001). Commitment in the workplace: Toward a general model. Human Resource Management Review, 11, 299-326.

Meyer, J.P., Stanley, D.J., Herscovitch, L., \& Topolnytsky, L. (2002). Affective, continuance, and normative commitment to the organization: A meta-analysis of antecedents, correlates, and consequences. Journal of Vocational Behavior, 61, 20-52.

Morris, M.H., Williams, R.O., Allen, J.A., \& Avila, R.A. (1997). Correlates of success in family business transitions. Journal of Business Venturing, 12, 385-401.

Nicholson, N. (2015). Primal Business: Evolution, kinship and the family firm. In S.M. Colarelli, \& R.A. Arvey. The Biological Foundations of Organizational Behavior. Chicago: University of Chicago Press.

Patel, P.C., \& Cooper, D. (2014). Structural power equality between family and non-family TMT members and the performance of family firms. Academy of Management Journal, 57, 16241649.

Restubog, S.L.D., Florentino, A.R., \& Garcia, P.R.J.M. (2010). The mediating roles of career selfefficacy and career decidedness in the relationship between contextual support and persistence. Journal of Vocational Behavior, 77, 186-195.

Rhoades, L., \& Eisenberger, R. (2002). Perceived organizational support: A review of the literature. Journal of Applied Psychology, 87, 698-714.

Royer, S., Simons, R., Boyd, B., \& Rafferty, A. (2008). Promoting family: A contingency model of family business succession. Family Business Review, 21, 15-30. 
Rudy, D., \& Grusec, J.E. (2006). Authoritarian parenting in individualist and collectivist groups: Associations with maternal emotion and cognition and children's self-esteem. Journal of Family Psychology, 20, 68.

Schaefer, E.S. (1965). A configurational analysis of children's reports of parent behavior. Journal of Consulting Psychology, 29, 552.

Schludermann, E., \& Schludermann, S. (1970). Replicability of factors in children's report of parent behavior (CRPBI). The Journal of Psychology, 76, 239-249.

Schröder, E., \& Schmitt-Rodermund, E. (2013). Antecedents and consequences of adolescents' motivations to join the family business. Journal of Vocational Behavior, 83, 476-485.

Schultheiss, D.E.P., Kress, H.M., Manzi, A.J., \& Glasscock, J.M.J. (2001). Relational influences in career development: A qualitative inquiry. The Counseling Psychologist, 29, 216-241.

Sharma, P., Chrisman, J.J., \& Chua, J.H. (2003). Predictors of Satisfaction with the Succession Process in Family Firms. Journal of Business Venturing, 18, 667-687.

Sharma, P., De Massis, A., \& Gagne, M. (2014). Family business: A fertile ground for research on time, teams and positive organizational study. European Journal of Work and Organizational Psychology, 23, 674-679.

Sharma, P., \& Irving, P.G. (2005). Four bases of family business successor commitment: Antecedents and consequences. Entrepreneurship Theory and Practice, 29, 13-33.

Sharma, P., Salvato, C., \& Reay, T., (2013). Temporal dimensions of family enterprise research. Family Business Review, 27, 10-19.

Shore, L.M., \& Tetrick, L. (1991). A construct validity sutdy of the survey o perceived organizational support. Journal of Applied Psychology, 76, 637-643.

Sieger, P., Fueglistaller, U., \& Zellweger, T. (2016). Student Entrepreneurship 2016: Insights From 50 Countries. St. Gallen/Bern: KMU-HSG/IMU.

Stajkovic, A.D., \& Luthans, F. (1998). Self-efficacy and work-related performance: A metaanalysis. Psychological Bulletin, 124, 240.

Suitor, J.J., Sechrist, J., Plikuhn, M., Pardo, S.T., \& Pillemer, K. (2008). Within-family differences in parent-child relations across the life course. Current Directions in Psychological Science, $17,334-338$. 
Tabor, W., Chrisman, J.J., Madison, K., \& Vardaman, J.M. (2017). Nonfamily members in family firms: A review and future research agenda. Family Business Review, 0894486517734683.

Turner, S.L., Alliman-Brissett, A., Lapan, R.T., Udipi, S., \& Ergun, D. (2003). The career-related parent support scale. Measurement and Evaluation in Counseling and Development, 36, 83-95.

Turner, S., \& Lapan, R.T. (2002). Career self-efficacy and perceptions of parent support in adolescent career development. The Career Development Quarterly, 51, 44-55.

Van Knippenberg, D., \& Sleebos, E. (2006). Organizational identification versus organizational commitment: self-definition, social exchange, and job attitudes. Journal of Organizational Behavior, 27, 571-584.

Verbeke, A., \& Kano, L. (2012). The Transaction Cost Economics Theory of the Family Firm: Family-Based Human Asset Specificity and the Bifurcation Bias. Entrepreneurship Theory and Practice, 36, 1183-1205.

White, M.J., \& Kaufman, G. (1997). Language usage, social capital, and school completion among immigrants and native-born ethnic groups. Social Science Quarterly, 385-398.

Zellweger, T. (2017). Managing the family business: Theory and practice. Cheltenham, UK: Elgar Publishing.

Zellweger, T.M., \& Dehlen, T. (2012). Value is in the eye of the owner: Affect infusion and socioemotional wealth among family firm owners. Family Business Review, 25, 280-297.

Zellweger, T., Sieger, P., \& Englisch, P. (2012). Coming Home or Breaking Free? Career choice intentions of the next generation in family businesses. Ernst \& Young.

Zellweger, T., Sieger, P., \& Halter, F. (2011). Should I stay or should I go? Career choice intentions of students with family business background. Journal of Business Venturing, 26, 521-536.

Zhao, H., Seibert, S.E., \& Hills, G.E. (2005). The mediating role of self-efficacy in the development of entrepreneurial intentions. Journal of Applied Psychology, 90, 1265-1272. 
Figure 1. A Model of Next-Generation Engagement in Family Firms

\section{Perceived Parental Behaviors}

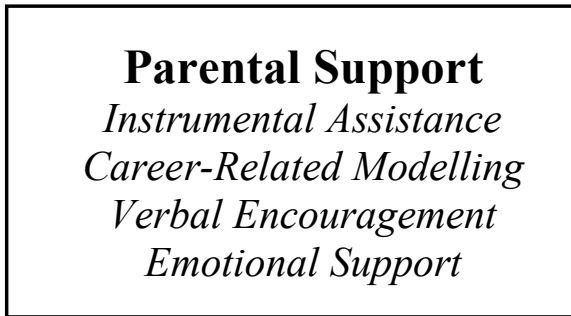

arental Psychological Control
Next-Gen Attributes

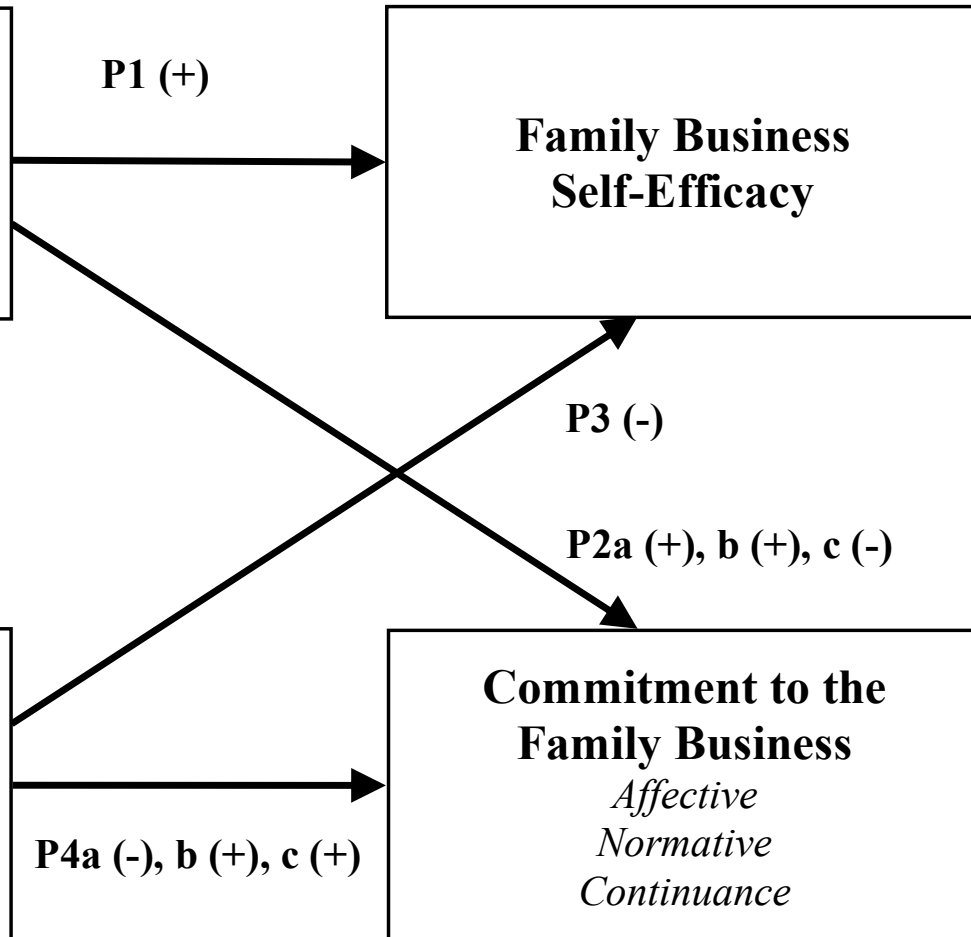

Continuance
Next-Gen Behavior

P5 (+)

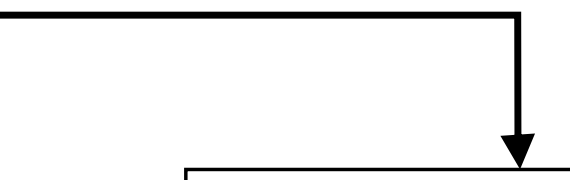

Next-Generation

Engagement

in

Family Firms

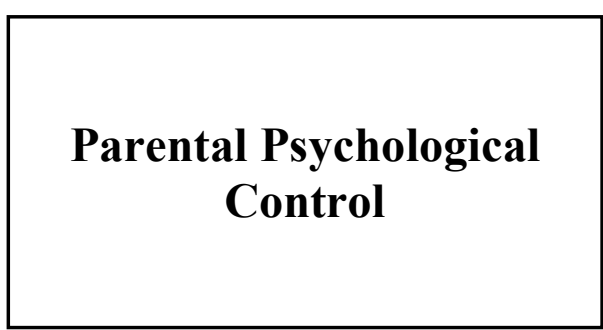

P6 (+) 